\title{
INTERNAL AND EXTERNAL BRANDING: A CASE STUDY OF SIMPO FURNITURE COMPANY
}

\author{
VANKA M. Gajo 1 \\ 1 Ivy League Club of Serbia, Belgrade (SERBIA), Serbian Management Association, Belgrade (SERBIA), BusinessAcademy \\ International School - LINK Educational Alliance | LEA, Belgrade (SERBIA), Confederation of International Accreditation \\ Commission | CIAC Global, Ahmedabad (INDIA), FasterCapital, Dubai (UNITED ARAB EMIRATES)
}

E-mails:gvanka@leomail.tamuc.edu; vankagajo@gmail.com; vankagajo@yahoo.co.uk; gajo.vanka@link.co.rs

\begin{abstract}
This paper focuses on corporate branding application. The research question here is if corporate branding can add value to the incubated furniture company, as well as how to connect corporate branding with value. When researching this question, it is necessary to research further on the division of corporate branding which is internal \& external (hereinafter referred to as „,int. \& ext.") branding, since a company added-value is from the cooperation and connection of int. \& ext. branding. Only when int. \& ext. branding work closely together, corporate branding may add more value to a company. In methodology, it was used a qualitative research method, which is company in-depth interviews, in order to research SIMPO's int. \& ext. branding experience. This case study is helpful to analyse how corporate branding is connected to an enterprise value. Through SIMPO's case, being the largest furniture manufacturer and among the largest companies in terms of turnover in Serbia which has been a de facto state-owned business incubator for the majority of light manufacturing companies in and around the city of Vranje, it is illustrated that int. \& ext. branding must combine in order to add value to a company. Corporate branding can really create value by increasing more adaptability/uniqueness/recognition. All in all, corporate branding is significant and can add value to companies. Corporate branding will play a more significant role in future marketing competition, so research on the corporate branding is likely to become more meaningful and interesting.
\end{abstract}

Keywords: added value, business clusters, business incubator, case study, competition, corporate brand, innovation, internal \& external branding, research projects, technology.

JEL: L20, L32, L68, M21, M31, O14.

UDC: 005.936.43:684(497.11)

COBISS.SR-ID 277965324 


\section{INTRODUCTION}

This paper's focus is on corporate branding and it concentrates on the influence of branding on an enterprise value. Corporate branding is likely to become more important in future. Successful branding can deliver better service and satisfaction to the customers. Many companies have realised its great significance for their relationship with consumers, as they can deliver more and better service and have a better reputation. Furthermore, corporate branding can also bring more profit to the brand owner. Corporate branding may play an important role in marketing competition and will surely become one of the deciding factors in future competition. It cannot neglect the human factor either, since people are an important resource that can supply more power to corporate branding. People are operators and executors of corporate branding. On the other hand, external branding may supply a platform for people to manage a company's brand. This paper goes through a case study to look at branding and its ability of adding value to companies, and it looks at the relationship between branding and value. This study is based on the Aaker and Joachimsthaler's theory (2000) when doing analysis of branding as a means to add value to companies. Aaker and Joachimsthaler (2000) have the clear statement that there are close collaborations between branding and value. McCracken (1993) stated that branding has value (it turns out) because it adds value. Branding may add value to the companies in ways like increasing more adaptability/uniqueness/recognition and creating better segmentation. The chosen company here can supply a successful model of branding. Especially when it comes to the combination of int. \& ext. branding, therefore, it can better support the viewpoint of the research that branding can be regarded as a means to add value to companies.

\section{BACKGROUND}

Nowadays, global marketing is extremely challenging. Today, for every firm a critical question for it success is that how it can maintain its current customers and how it can make them loyal to the brands (Vanka, 2011). The international market environment is changing faster than ever before. Serious competition gives increased challenges to traditional brands. Vossoughi (1999) mentions that the competition in the future will not only be through price, quality, position and more important is the branding. Berry (1993) stated that numerous competitive variables determine success and new factors are emerging and interacting all the time. The business environment is changing faster than ever before, such changes are occurring in two major dimensions, complexity and turbulence (Robbins, 1990; Achrol, 1991). The overall business environment is more and more complex and challenging. Knox and Walker (1995) stated that branding is a process that takes control over everything the brand does and says. The overall aim of this process is to increase the value of the brand over time. Future competition will focus more on branding instead of the traditional focus on price, quality and position. So how significant will branding become? And what is the focal point about branding? Should it bring more satisfaction to the customers, or should it add more value to companies, so to speak?

\section{Problem statement(s)}

This paper focuses on branding with relation to its processes, division and its collaboration with the enterprise value. In view of the above, the research questions can be defined as the following two points: Can branding act as a means to add value for companies? Can int. \& ext. branding work separately? What is the relationship between int. \& ext. branding when adding value to companies? 


\section{Purpose of the research study}

Many aspects of brand have drawn attention to branding these years. There is no company that can neglect the great advantage of branding anymore. The purpose of this paper is on the basis of theoretical issues, through case study to discover the relationship between branding and value - how they connect with each other. Motivations when companies use branding also includes the process which combines int. \& ext. branding. In this research, it was discussed how they react to each other. Aaker and Joachimsthaler's (2000) theory on the division of branding related to value has supplied a necessary theoretical support to this research study. The research study is based on a conceptual framework for the corporate branding and enterprise value; exploring branding's influence on the enterprise value.

\section{Study hypothesis \& limitations}

This research paper goes through a case study to look at branding and its ability of adding value to companies. It also looks at the relationship between branding and value. When discussing adding value to companies, it is necessary to concentrate on int. \& ext. branding, because these two, and the way they are managed, make a necessary condition when adding more value. The chosen enterprise SIMPO Vranje can supply a good model to some companies, especially when it comes to the combination of int. \& ext. branding. Therefore, it can better support a research viewpoint that branding can be regarded as a means to add value to companies. This selection of companies delimits this study to only investigate companies that possess a successful branding history. The products process to the consumer is not investigated. This study is limited to investigating a company with a great brand operating in the international market. The study is also limited to the present time and do not consider historical or future actions taken by the company. There are no foreseeable, substantial cost implications in carrying out the necessary research for this study. As mentioned, resources are widely available on the subject of business practices pertaining to quality, product, and service. A minimal cost for office supplies pertaining to the distribution of the survey literature was imposed on the researcher, but has not, in any way, affected the results of this research study.

\section{Previous research studies}

According to Kotler's statement (1997) branding's function is planning a long-term brand strategy, it should watch over a brand's profit, since working closely with advertising agencies to build market share and long term consumer brand loyalty. If this is the case, then the efficacy of many brand managers must surely be to concern (about) these branding questions. However, according to Coupland et al. (2005), who writes that strong branding is built up through a cocreation process involving a number of players, especially the company's core values and brand managers. Sherry (1998) points out that the successful branding derived from an act of cocreation transaction by the company's stakeholders. Coupland et al. (2005) demonstrates that the technologies-based branding is a positive driver in the company's core values. Thus, as Brown et al. (2003), note the branding is a milieu where the company's core values coexist. Kotler (1997) researches branding which is based on differentiation; representing the distinctiveness of a product from that of competitors. Another is added core value that states a branded article has more value for the customer than an un-branded one (Krake, 2005). Kotler (1998) also writes that the yield from a long-term brand strategy will be far greater to provide the explanation about the impact on three areas, financial, strategic and managerial. On the 
other hand, Voerman (2003) also confirms that companies that offer strong brands enjoy significant advantages to those that do not. Aaker (1996) stated that there are four key brand assets from which branding is derived. The four brand assets in branding lists are - the perceived quality of the brand, brand awareness, brand loyalty and brand associations. These assets are in close relationship with branding. Branding actually has big influence from other issues like brand identity. The branding aims at creation of value. According to De Chernatony and McDonald (1992), the aim of brand movement is to facilitate the company's task of getting and maintaining a loyal customer base in a cost effective manner in order to achieve as high a return as possible on the value. Comparing with Voerman (2003), Kotler (1997) stated that the two basic factors of branding are differentiation and added values (benefits) respectively. Referring to previous theories, this research paper regards to the following two points:

- In the first statement, Kotler (1997) and Voerman (2003) have stated that branding is related to push strategy in order to support brand awareness. Much research has been done on either branding or enterprise value. Even though, as Kotler (1997) and Voerman (2003) are only focused on branding as a long-term strategy in the market and company's management process, they are orientated on customer's awareness as well as customer loyalty and awareness of the product, but they neglect branding's relation to the company value, the value can be realised as a brand asset. Some people also do research on the enterprise value only, which neglects the connection with branding. The research object here is concerned with the relationship between branding and enterprise value. In that way, both branding and value are important tools in marketing expansion and business operation. Therefore, researches on combinations, find that the relationship of an enterprise value and branding is meaningful. Here, this study focuses on branding's collaboration and connections with value.

- In the second statement, company's competition between different products in the future will concentrate on competition between the different brands and branding will become more significant, as that is what may bring more satisfaction, service (etc.) to the customers, and may add more value to companies. Aaker and Joachimsthaler's (2000) theory have a clear statement on the collaborations between branding and value, this view here can support the research question. The Aaker and Joachimsthaler's (2000) view can supply a good framework and theoretical basement. McCracken (1993) also has similar ideas and stated that branding has value because it adds value. Therefore, chosen theory in this paper comes from Aaker and Joachimsthaler's (2000) and McCracken's (1993).

There are many definitions of branding. Ryder (2003) has the definition that branding is the application of marketing techniques to a specific product, product line, or brand. It seeks to increase the product's perceived value to the customer, thereby, increase brand franchise and brand equity. Comparing with Ryder (2003), Davis (1995) indicates that branding should take a long-term perspective and suggests that organisations wants to change the ways that they are managing their brands much more like assets increasing their value over time. Branding tries to increase value for customers and ultimately, increase sales volume (Ashtiani and Bahmanzadeh, 2017). The basic idea of using a brand refers to the enhancement of the value of a product when the producers/manufacturers realise that the price competition leads to lower profitability or to a decrease/reduction in profitability (Satvati et al., 2016). Satvati et al. (2016) also points out that profitability reduction (or the decrease in profitability) through price competition has made or has led manufacturers/producers to apply methods to increase customer loyalty, brand value and brand equity. Clearly, it is important that branding is working towards a common goal and a mechanism for achieving competitive advantage for companies, through differentiation, which creates the core 
value for the companies. It is relationships that would exist if brand equity were to be managed both strategically and operationally. Here it is referred to Aaker and Joachimsthaler's (2000) viewpoint to describe branding as a great function positive influence on the enterprise value. His concept of branding is closer to the practical experience which can then better support this research study. Aaker and Joachimsthaler (2000) illustrate the branding in a way that can conclude that branding is a long-term process, changing the ways of managing a brand which can relate to and increase value. Comparing with other theories, Aaker and Joachimsthaler's theory better supports the research questions, because Aaker and Joachimsthaler (2000) stated that branding has a positive influence on the enterprise value.

\section{The connection between branding and enterprise value}

The term branding is used and expanded on by many authors. Van Kralingen (2002) mentions branding as part of identity, stating that the branding can be viewed as the glue/bond that holds the core identity elements together. Upshaw (1995) also sees that branding can positively influence an enterprise value and the significant core of companies is the branding. Keller (1999) states about that branding's soul is its spiritual centre. Randazzo (1993) also states that branding connects to the value. However, McCracken (1993) pointed out a discussion concerning branding which provides a good overview that it can add value. According to Aaker and Joachimsthaler (2000), branding may add value in the following ways: 1 st - Segmentation, to match the values of the brand to lifestyle requires brand innovation and may supply greater credibility to company's consumers, 2nd - Recognition can help to rapidly establish credibility in new markets, 3rd - Uniqueness to express the uniqueness of position to all int. \& ext. audiences and 4th - Finally, adaptability to let brands adapt to the local marketplace while fulfilling a global mission. Aaker and Joachimsthaler (2000) addressed the great influence of an enterprise value which can add adaptability/uniqueness/recognition and segmentation; he also stated that the branding is regarded as push strategy. Branding can create an enterprise value like supplying more adaptability/uniqueness/recognition and segmentation to a company. Based on Knox and Walker (1995) stated that branding is a process that takes control over everything the brand does and says, managing the way in which it is perceived by others. The overall aim of the process is to increase the value in branding over time. Actions have been influenced by the purpose - adding value to companies. Aaker and Joachimsthaler (2000) argue that added-value/benefit includes the value proposition and functional and emotional discriminators. Enterprise value is the term that Knox and Maklan (1998) and later on Knox et al. (2000) particularly mentions is to express what the customer is prepared to exchange for a brand. Jones and Morgan (1994) speak of adding value, and here they are talking about the process of developing brands. Keller (1993) conceptualises branding using an associative memory model focused on brand knowledge and involving two components: brand awareness and brand image - described as a set of brand associations. Using this conceptualisation of branding, Pitta and Katsanis (1995) claim that the leadership can create and enhance brand awareness, then build on this foundation and craft a salient image composed of a group of positive associations about the brand. Pitta and Katsanis (1995) also argue that proper management of these elements helps to create a level of awareness in the target audience, and careful creative activities can form a brand's identity in the consumer's mind. Specifically, Pitta and Katsanis (1995) are concerned that those assets represent the knowledge created in the minds of consumers as a result of all of the marketing programs executed for those brands. Pitta and Katsanis (1995) concluded that in one sense it can be viewed as the result of the total resource investment in the marketing of the brand. According to Keller (2000), branding should always relate to the value of the company. Then branding has really connected with the company's core value. 


\section{Internal \& external branding model with value}

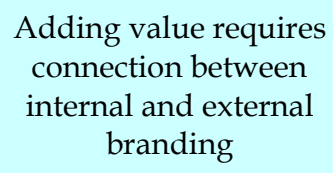

Adding value requires connection between internal and external branding

Branding can
add value
like
increasing
adaptability/
uniqueness/
recognition
to
enterprises.
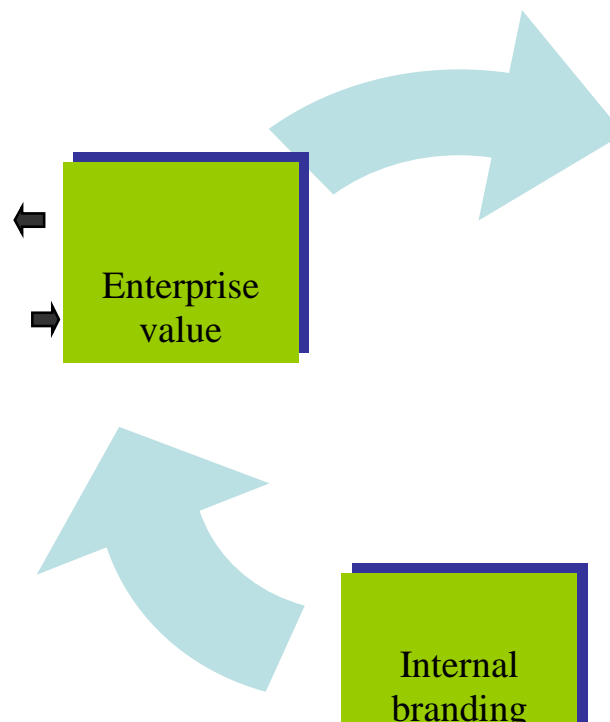

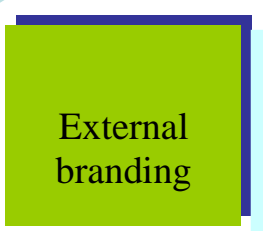

Managing brand factors which relate to product, design, price, quality ...

Managing brand factors which concern organisation's HR vision, acknowledgement, idealism, team communication, staff's cooperation ....

Fig. 1. Adding value with the internal \& external branding model

\section{Source: based and referred to Aaker and Joachimsthaler (2000)'s Brand leadership.}

The research model is focused on the relationships between branding and value. Branding includes the int. \& ext. branding. These frameworks address that int. \& ext. branding should combine together and work closely to create value. The combination of the two factors can make them promote each other as well as increasing value to companies. External branding can supply a necessary platform for internal branding, while internal branding as necessary executor can assist external branding and positively influence enterprise value, though both int. \& ext. branding use different paths to manage a company's brand (Aaker and Joachimsthaler, 2000). Keller (2000) also describes that enterprise value can be regarded as the differential response by consumers, customers, employees, other companies, or any relevant constituency to actions, communications, products or services. However, both int. \& ext. branding cannot work alone. They should connect closely, and work cooperatively. The framework builds on the idea that a branding is developed as a continual and on-going interaction between a company and its customers. In this way, the organisation's values can therefore be seen as symbols of an organisation's efforts and ambitions on branding.

\section{Internal branding versus external branding}

Aaker and Joachimsthaler (2000) stated that the value-creating processes take place in parallel. These are an internal - within the organisation; and the external - in the awareness of customers. Aaker and Joachimsthaler (2000) have mentioned that branding can be divided into int. \& ext. branding. As earlier stated, the objective of this internal process is ultimately to create value having in mind the customer's identity as the basis. Aaker and Joachimsthaler (2000) 
stated that the employee in the internal branding is executor and operator of branding. According to his viewpoint on value, it is necessary to discuss internal together with external branding and their connection with value. Balmer and Wilkinson (1991) stated that internal branding consists of the organisational resources available to accomplish its goals. These include work ethics and personal values, general cultures and physical resources. One of the important tasks of branding is to acquire these resources and make efficient and effective use of them within an organisation. Internal branding relates to the organisation, human resource factors, etc. Aaker and Joachimsthaler (2000) have stated that internal branding is related to identity, image and vision. Organisations own understanding of the brand and its commitment. According to Wernick (1991) an organisation's relationship with its brand will also affect the total internal relationship to the enterprise value. In this study, internal branding is related to factors like human resources, identity, and organisation's image. The external brand building process is primarily concerned with the relations and interactions between the brand and its customers. The objective of this external process is ultimately to create relationships with the customer's identity. To achieve a strong brand relationship with the customer, it is necessary for there to be an interest in the product and for the choice of brand to be regarded as important; there must be brand sensitivity (Kapferer, 1992). External branding in this research paper is related to factors like product quality, package and so on. Also, external branding supports the internal branding to service a company's brand. External branding is able to supply a necessary platform for internal branding and it is difficult for them to work separately (Aaker and Joachimsthaler, 2000). Both int. \& ext. branding use different ways to increase the brand awareness and customer loyalty to the brand. Therefore, both of the two factors should combine, connect closely, work cooperatively and support each other to create value. In general, according to Aaker and Joachimsthaler (2000) external branding can supply a necessary platform for internal branding, internal branding as executor and operator can support external branding and thereby positively influence the enterprise value.

\section{RESEARCH METHODOLOGY}

Research was done on a small sample (qualitative research - interviews with experts). Qualitative research is chosen as research method. In this method, an interview was conducted in a case study with different respondents. Respondents are from SIMPO's group and are in charge of their marketing and branding department in Serbia.

\section{Qualitative method}

For the qualitative research is chosen Serbian company SIMPO Vranje as a case study, which means that specific data and facts were gathered during in-depth interviews with respondents. Respondents are in charge of brand management in SIMPO's marketing division. The key respondent's position is a brand manager in their brand management department. In interviews, the researcher had the chance to speak freely. The interviews took place at the respondent's office for two times, and each in-depth interview lasted at least about one hour. There are many reasons to choose SIMPO as a case. For the first, SIMPO is Serbian as well as a Balkans leading furniture brand; meanwhile this company has successful branding experience from the last twenty years. SIMPO's successful combination of int. \& ext. branding has created sustainable profit, splendid reputation for the brand. SIMPO's branding really seems to bring satisfactions to the customers. These research questions focus on the combination of int. \& ext. branding. The theoretical part is based on the two relationships, internal versus external 
branding, branding versus value. The in-depth interview was conducted in a qualitative method to pass through the SIMPO's case, and the necessary data/facts were acquired and gathered from respondents in SIMPO's brand management department. As the research uses a case study method, it is based on both types of data - primary and secondary, and distinctions are made between them. When collecting the primary data, we had the chance to converse/speak with the respondents more than a few times in order to evade uncertain misunderstandings of data and facts. This research method really helps to illustrate and research the connections between int. $\&$ ext. branding and between branding and value.

\section{Case study profile: Background of SIMPO's operations}

SIMPO is a shareholding company, with headquarters in Vranje, in southern Serbia, with furniture production and wood processing as its core activities. SIMPO group offered series of home furnishings and accessories of home design with fine/good functionality. Founded in 1963 as a Sima Pogacarevic furniture factory (named after a local fighter from Second World War), the company was unsuccessful in its first four years, until in 1967, when the new CEO was appointed. Then began a period of growth and prosperity for the company. A company with three hundred seventy employees transformed into one of the most successful Yugoslav companies. The company SIMPO was established in Vranje (small town in south of Serbia) and from a small furniture factory it has evolved into a joint stock company with near seven thousand employees. In 1980s, the management decided to diversify the product portfolio and fully integrate the manufacturing process via in-house production of intermediate goods. A number of new lines were introduced, including textile production, fine wood processing and chemicals production. Vertical integration yielded substantial results and the company managed to significantly increase its size and turnover by the beginning of 1990s. SIMPO has vertically integrated the furniture manufacturing process through deployment of several wood and textile processing plants, in order to ensure stable supply of all inputs. Apart from furniture production, the company has also positioned itself in other industry segments such as chemicals production, retail, as well as agricultural and food production. Before the dissolution of former Yugoslavia, SIMPO was the largest furniture manufacturer in a twenty million people market. Due to a time gap between furniture manufacture and sale, the management was forced to enter a range of activities which involved fast turnover goods production in early 1990s. Thus the diversification strategy was also pursued in the last fifteen year period when the company entered a range of agricultural and food production activities and introduced several new wood processing facilities. SIMPO is a production-business group, as well as one of the largest and most successful Serbian companies. Major Fields of development of SIMPO's activities are production of furniture, food industry, trade and transportation. Strategic principle according to which SIMPO has been developed is the rounding up of the production process (from production of wooden construction materials and materials for reproduction, to the production of a most elite final product of superior design, quality and functionality), by which the company is unique in Europe. Modern equipment and state-of-the-art technology are being used, which have been adapted to the technological and ecological criteria of the European Union. Major factories of the SIMPO Company are:

- The furniture factory - SIMPO's core business activity is classified as furniture production

- The factory of upholstery and leather seats

- The factory of laminated furniture 
- The crib factory

- The mattress factory

- The decorative fabrics factory.

The SIMPO joint-stock company is a system composed of eighty companies and production units operating in several business activities - manufacturing and sale of furniture, as its main activity, but also in the food industry, agribusiness and services. With its long tradition in wood processing industry, the company is involved in almost every segment of wood processing, producing both intermediary and final products. With the introduction of Laminated Furniture Factory, Interior Furniture Design Factory, Upholstery Factory and Mattresses Factory, the company has successfully integrated the furniture manufacturing process through in-house production of all the required elements. A furniture production process in SIMPO is conducted in the facilities such as Sawmills (sawmill wood processing), Casing Construction Factory (production of casing (wood) constructions for manufacturing of tapestry garnitures, bolsters and bedrooms), Factory Stil Surdulica (manufacturing of solid parts, where wood frameworks for massive and stylish furniture are being produced, as well as surface finishing of garnitures parts), Furniture Factory and Interior Furniture Design Factory (production of household furniture i.e. bedroom and kitchen elements), Mattresses Factory, Tapestry Factory and Gearing Factory (production of chairs for the market, and manufacturing of platforms and metal gearings for bolsters and tapestry garnitures for other companies within SIMPO). Apart from its core activity, SIMPO is engaged in a number of other businesses through its subsidiaries such as: SI-MARKET - retail trade of food and beverages s incorporated through a merger with several small and medium sized retail chains; KONDIVA - confectionery production company; SIMPO TEPISI - production of carpets and floor coverings; SIMPO-COMMERCE - wholesale of wood products and construction materials; SIMPO LINE - engineering and interior furnishing; SIMPO DEKOR - production of cotton materials or textile manufacturing generally; SIMTAK - upholstery production; SIMPO VLASINA - animal farming; Simpo Cveće - horticulture; SIMBI - trading medicinal herbs; SIMHEM - phosphate free detergent production; SIMPO DRVO - production of grave wood; and VESO PO - production of nonalcoholic beverages. It employs about five thousand workers, who mainly work in the production facilities concentrated in the most undeveloped municipalities in the south of Serbia and in the north of Kosovo and Metohija, in Zubin Potok. The business concept of SIMPO is fully dedicated to the development of the south of Serbia and better standard of living of the people living in that region, which is confirmed by the fact that today SIMPO employs as many as $28.2 \%$ of the total number of employees in the manufacturing industry of the entire Pcinja District. With the annual production worth more than seventy million euros, it has had a substantial share in the generation of GDP and it is an important economic factor in the country. In 2012, SIMPO exported to the markets of thirty countries $54 \%$ of its annual production.

\section{RESULTS AND DISCUSSION}

Results and discussion section contains case study analysis, as well as further managerial $\&$ business performance implications.

\section{Current facts about SIMPO}

SIMPO was a leading furniture producer and exporter in former Yugoslavia, but production stalled during the 1991-99 Balkan wars and Serbia's international isolation until the change of 
government in 2000. According to its official website, the company is worth (at least) an estimated eighty million euros. SIMPO's estimated worth is seventy million euros, and $70 \%$ of the company is jointly owned by the state and small shareholders. Since the restructuring of its ownership structure in 2002, 59.5\% of its stakes have belonged to small shareholders. A further $10 \%$ and $30.5 \%$ belong to the state-run Retirement Fund and Share Fund respectively. Because of its location, SIMPO has been described as a company of strategic importance for Serbia and a guarantor of the future economic growth of the whole region. The problems facing SIMPO are causing great upheaval among the small shareholders who own about $26 \%$ of the company. In addition to the debts it owed the state, SIMPO owed a further forty million euros to suppliers and public companies for unpaid utility bills and fuel. After the change of government in 2000, SIMPO had to repay to the state debts amounting to one hundred fifty million euros, due to excess profits generated thorough borrowings at favourable rates from state-owned banks. Due to that, the government had obligations towards SIMPO, and the state is obliged to return to SIMPO one hundred fifty million euros collected as excess profits, as it has done with other companies. In addition, SIMPO used to own property in the other countries of the former Yugoslavia, with a value around one hundred eighteen million euro. SIMPO's shares have plummeted on the Belgrade stock exchange to below thirty euros, close to half their value a year ago, because of the extent of its debts. The possibility that saved the company was being to reschedule its debt to the state.

\section{SIMPO group - incubated companies}

SIMPO Group has a complex organisational structure as a result of the diversification of its business operations and deals with several economic activities - manufacturing and marketing of furniture, food industry, agribusiness and services. Today, SIMPO comprises a team of five thousand associates in thirty enterprises and several dozens of production plants. The majority of production capacities are located in southern Serbia in the vicinity of the city of Vranje. SIMPO has been operating on the international market for more than forty years, and today it exports its products to three continents, and to more than thirty countries - worldwide with an export representing 65\% of production. According to Stosic Mihajlovic (2013), until recently it was present on the international market, in almost every continent. An average annual export growth of $20 \%$ confirms that the foreign buyers, whose number has been increasing by $30 \%$ on average every year, have recognised SIMPO as a reliable and demanded partner. SIMPO is a leading regional company trading in furniture and accessories, with its own logistics and the retail network of sixty department stores and showrooms in five countries. Within the wide range of its activities, the core business of the SIMPO Group is furniture industry, in which it ranks among the largest European manufacturers. The company was ranked among Serbia's top eighty-five companies in terms of operating revenues in 2008: dropped out from 2005's top sixty companies ranking; and twenty-five largest exporters in 2008 bringing up to 19.56 million euros in exporting goods: with a slight increase above 18.3 million euros in 2006. In terms of ready-made goods, SIMPO has achieved highest output level in 2005. In 2009 despite the economic downturn and low level of bank financing, SIMPO achieved growth in sales compared to 2008 and the highest sales growth were recorded in mattresses and cupboards segment. In this activity, the company has the rounded-off production process, from raw materials and intermediate goods to final product, which makes it unique on the European market. Such a concept enables the maximum control of quality, costs and just-in-time delivery, which makes their products competitive both on the domestic and international markets. 


\section{Export growth and new markets in spite of the crisis}

According to Lotfifard and Borojerdi (2018), marketing mix (product, place, price, and promotion) has a positive and significant effect on export performance. SIMPO has established a strong presence in both international and domestic levels with over one hundred seventy (170) retail outlets and over eighty (80) furniture retail outlets in prime locations in Serbia and the region. From the beginning of 2012, SIMPO has been exported to thirty countries and recorded an export growth of $25 \%$ as compared to 2011 (www.simpogroup.com, 2013). Export growth to the France is particularly important, because it is one of the most demanding Western Europe markets (ibid.). The agreements have been made with the French partners for export to that country in the value of ten million euros in the coming year (ibid.). These agreements are very important for the Serbian furniture industry, because they relate to the export of furniture with high prices and the original SIMPO design for the most exclusive trade chains (such as Crozatier, Cuir Centre and Roche Bobois), where the SIMPO's products will be placed in the special branded space with the made in Serbia mark/logo (ibid.). Along with the living room UNI, the sofa-bed program and their boardfurniture program is being sold on the French market as of 2014. SIMPO Company has made an important breakthrough in the Near East market (ibid.). At the end of August 2012, SIMPO's showroom was opened in the capital city of Kuwait in the area of more than eight hundred square meters, in association with a local partner, the company AFGI International (ibid.). Israel is a new market for SIMPO in 2012 (ibid.). With the company Wissmann, the largest furniture trading company in that country, with ten trade centres, SIMPO have agreed the cooperation that includes supplies of upholstery and board furniture for their facilities across Israel (ibid.). SIMPO Continues Supplying IKEA. The cooperation with the Swedish IKEA, their major partner, has recorded a twodigit growth in 2013, too. IKEA has placed an order for all articles from SIMPO's regular product portfolio, which it plans to market through its three hundred thirty-three stores in forty countries. KIKA, the Austrian chain, sells the SIMPO's furniture from the end of 2012 in Austria, Croatia and Serbia. In addition to that, it includes SIMPO's products in its centres in Romania from the end of 2012, and in Slovakia, the Czech Republic and Hungary from the current 2013, too (ibid.). According to Business Week (www.businessweek.com, 2013), SIMPO plans a biomass plant with Slovakia's Grafobal Group Energy.

\section{The leading SIMPO's product on the French market}

From the beginning of 2012, SIMPO has trebled the value of contracts on export to France and increased the deliveries to five million euros (www.simpogroup.com, 2013). Export of exclusive furniture trebled "Esterel Suite" which is the leading SIMPO's product on the French market. As of September 2013, the SIMPO's management agreed that the value of monthly deliveries would be around one million euros, and the first agreements were made for export to the French market (in the coming period) in the value of ten million euros. The agreements reached are especially important for the Serbian wood processing industry. That way, SIMPO Group has become one of the leading suppliers on the French market in the segment of exclusive furniture. SIMPO has made a powerful breakthrough on the demanding French market owing to the constant investments into innovations, design and market research, and the traditional superior quality of its products (ibid.). Following the most topical European trend of product personalisation, among other things, SIMPO enables its buyers in France to add details and functionality to the chosen model of sofas, according to their specific aesthetic requirements and needs (ibid.). Stosic Mihajlovic (2013) emphasises that with this approach SIMPO fully meets the national export strategy requirement as it increases exports and growth of GNP. 


\section{SIMPO the winner of the recognition awards}

The award "The Best of Serbia", as the best corporate brand for 2012 in the category of durable consumer goods was awarded to the SIMPO company, which has won this recognition for the record fifth time (www.pks.rs, 2013) - making SIMPO the absolute record breaker in the category also acquiring the status of the "Corporate super brands Serbia" 2012-2013 awards (www.simpogroup.com, 2013). In the traditional campaign organised by the Ministry of Trade, Agriculture, Forestry and Water Management, the Chamber of Commerce and Industry of Serbia and the daily business newspaper „Privredni pregled“, SIMPO won this national recognition also in 2005, 2008, 2009 and 2011. The campaign was launched in 2004, and it was focused on strengthening the image of domestic brands and competitiveness, with the support of innovativeness and the promotion of local brands. One hundred and fifty companies competed for twenty recognition awards „The Best of Serbia“ for 2012, in the category of the commodity, corporate, service and personal brands, and the winners were selected on the basis the financial results, market research and evaluation by business partners and consumers who voted via internet. The aim of Corporate super brands Serbia 2012-2013 awards, a leading global platform for brand promotion which exists in over ninety countries across the globe, was to award the most successful companies in Serbia by applying the strictest methods of selection with the key grading criteria which included public appeal \& reputation, lasting consistency \& reliability, corporate responsibility (via market with quality \& price \& services, corporate relations with legality \& transparency, working environment \& procedures, social responsibility with sponsorships, cultural \& public events and environmental protection). That is how seven of the best corporate super brands in Serbia were selected within each category.

\section{Success of SIMPO's external branding}

The external branding has brought great success to this company. SIMPO has kept a more than 10\% growing speed from 1998 in the global market and it has been experiencing hard competition during the 1990th. The turnover reached to 1.216 million euros in 1984 and 20.685 million euros in 2007, which means an increase of sixteen times over the last thirteen years (Figure 2). In the past ten years, it has kept an increasing advantage with their competitors, and they are now the absolute region leader in furniture design and product quality (source from respondents). It is important to train, empower, and reward employees so that they are able and willing to live with the brand when interacting with customers, suppliers, other partners, and mass media and so on. The foundation of SIMPO's success has been to offer consumers good value for money.

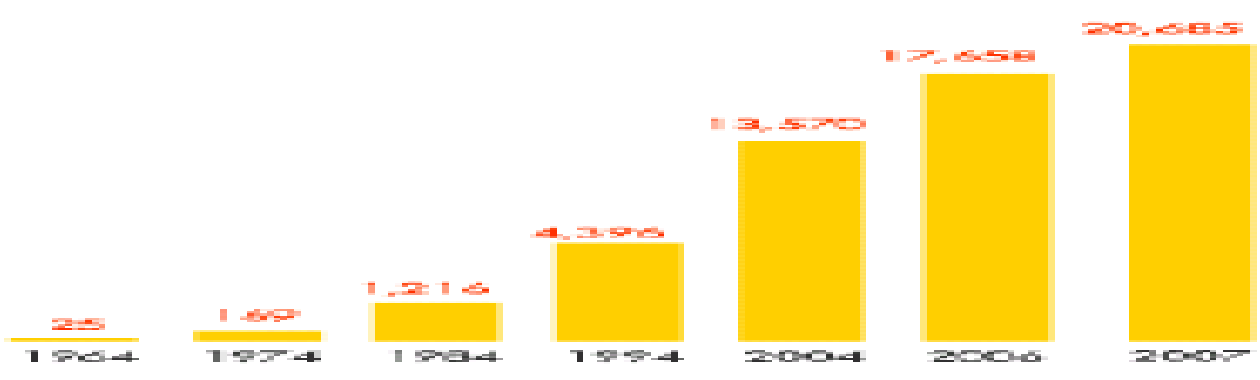

Fig. 2. Turnover of SIMPO store displayed in value of million euros - Sale tax not included Source: data obtained from the 2007's Annual Report - available at www.simpo.rs (2012) 


\section{Great results of internal branding}

SIMPO's internal branding has obtained great success. Internal branding has increased staff's enthusiasm. They are more active in contact and communication with customers, which is an important "energy factor" to sustain SIMPO's brand. Loyal customers, return despite offers by the competitors (source from respondents). The visiting customer's number has kept an increasing rate of $15 \%$ in the last twenty years. In 1984, there were around sixty thousand visitors to the SIMPO group, in 2007 there were approximately six million visits to SIMPO stores, a ten times increase.

\section{The basic structure analysis of SIMPO's branding}

The empirical findings were analysed through the analytical model presented in the theoretical framework. It focuses on the SIMPO Group to discover if the corporate branding can act as a means to add value to companies. After this, a summary of the analysis was made to create a clearer picture and find (or discover) the connections between int. \& ext. branding with value. In SIMPO's case of branding, innovative thinking is important as exemplified by its integration of form, functionality, and low price. SIMPO represents a modern and casual style. Providing people with a new identity and changing their homes (source from respondents). There are hundreds of inspirational displays in the SIMPO stores from realistic room settings to real-life homes, all with product combinations that provide fresh ideas and know-how/expertise supported by the knowledge of contemporary interior design. This gives visitors huge possibilities to find solutions that best suit their needs. Products in SIMPO are offering a wide range of well-designed, functional home furnishing products at prices so low that as many people as possible will be able to afford them. The SIMPO range includes products for every part of the home. Low price is a prerequisite for the SIMPO Concept to realise the SIMPO vision - to create a better everyday life. SIMPO keeps products at extremely low price levels (respondents' data source).

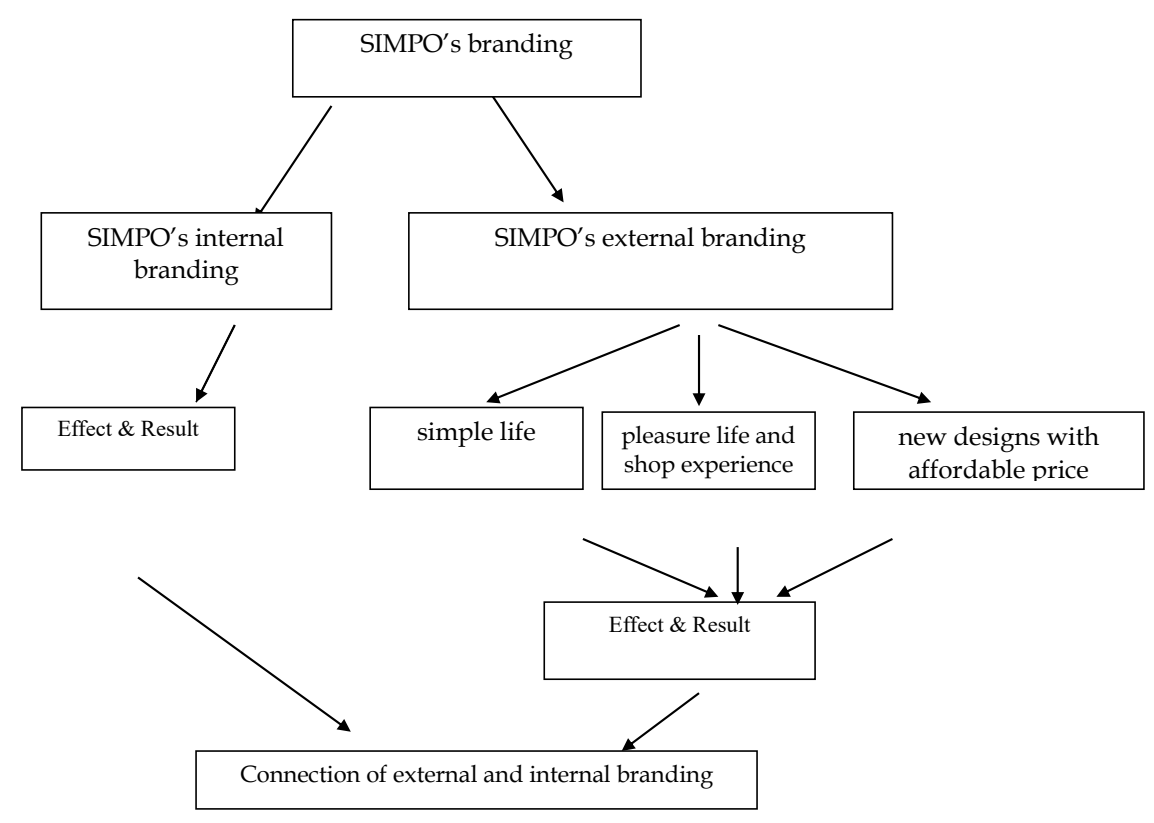

Fig. 3. The basic structure of SIMPO's branding which is a close combination of int. \& ext. branding

Source: Data obtained from respondents 


\section{The existence of internal branding without external branding:}

Internal branding is concerned around organisations, HR's visions, and acknowledgements. Balmer and Wilkinson (1991) and later on Balmer (1995) stated that the internal branding consists of the organisational resources available to accomplish its goals. These include work ethics and personal values, general cultures and physical resources. One of the important tasks of branding is to acquire these resources and make efficient and effective use of them within an organisation. These ethics, cultural \& personal value, and physical resources should be based on external branding as a necessary condition. SIMPO staffs manage brands; communicate with customers about brochures, design, etc. If internal branding do not cooperate with external branding, it will be very hard to add adaptability/uniqueness/recognition, to the company's brand, which then cannot add value to the company. Therefore, it is difficult for internal branding to work alone without external branding. Internal branding should work cooperatively and connect closely with external branding.

\section{The existence of external branding without internal branding:}

A company's brand can possess an affordable price, fine quality, good design, etc. However, no matter how many good points there are saying about it, it is not advisable to neglect the human factor. Human resources (HR) are significant in branding in order to add value to companies. The staffs are an important factor that encourages customers to buy from you and not your competitors even when there is product parity and similar pricing (Drees, 2006; www.brandchannel.com, 2006). It is perhaps the most challenging part of branding's factor. There is a profound effect on customer loyalty when it comes to employees, whether being distributors, managers, etc., and according to Drees (2006) it has been proven that people are a powerful part of the customer loyalty equation. Their knowledge about the brand or service, their friendliness and approachability, their motivation and dedication to serving the customers are all tied directly to a company's brand and its course in connecting adaptability/uniqueness/recognition to the company's brand. It is no surprise that some companies with highly qualified people have the best brands. If there were no internal branding in the SIMPO plush dog case, maybe this brand would have failed. External branding factors need the support from internal branding factors in order to realise its functions and purpose to increase the adaptability/uniqueness/recognition of the SIMPO brand or whatever brand for any company. Therefore, it is difficult for external branding to exist without internal branding.

\section{Branding add value by way of increasing more adaptability/uniqueness/recognition:}

Referring to the theoretical section, McCracken (1993) stated that branding has value because it adds value. The discussion in De Chernatony et al. (2000) about the branding that can add value provides a good overview. Upshaw (1995) also saw that branding can positively influence value, and the core of the core is - the branding. Regarding theoretical issues, Aaker and Jacobson (2001) have mentioned that branding can increase adaptability/uniqueness/recognition, which then connects to an enterprise value. SIMPO manage their brands to draw people's attention through splendid design, colourful display rooms, and by bringing new inspiration and fashion ideas to their customers. The SIMPO brand requires shops to innovate for people like including some kind of entertainment place or relaxing area. Their branding greatly increases brand awareness, and so, in this way, customers are more loyal to the SIMPO brand. Customers feel great comfort and care when SIMPO offer 
employee's excellent service. People become more and more loyal to SIMPO's brand. Purchase in SIMPO is not only a payment, but also an enjoyment, a taste of the brand. People who are attracted by this well-managed brand, will most likely adapt SIMPO's new products, new designs. Branding can improve adaptability to companies. Management of a brand is in order to keep competitive advantage to brand competitors, so companies try to manage their brand in a unique way compared to others. Branding includes improving a brand's visual impression and to give it a personal image, in this way, people can easily remember a certain brand. At the same time, companies can obtain more uniqueness by running brands this way. Recognition comes through branding which means branding can spur your customers to be more loyal to your brand. Vanka (2011) claims that corporate recognition can be gained through corporate branding which is helpful for better market share. Branding has a positive influence by increasing adaptability/uniqueness/recognition to the companies. Similarly, adaptability/uniqueness/recognition directly leads to the enterprise value. Branding can add value by way of increasing more adaptability/uniqueness/recognition.

\section{Branding add value through the combination of internal \& external branding:}

According to McCracken (1993) in an increasingly competitive global marketplace, it is ever more important for companies to ensure branding. He further stated that branding has value since it adds value. Speak (1998) mentioned that branding can enhance a company's relationship-building skills. All these researchers have clear statements that there are close collaborations between branding and value. Branding can add value to the companies by way of increasing more adaptability/uniqueness/recognition. Branding increases employee engagement; offers a strong vision and attracts customer's attention. SIMPO's branding steps make this brand more distinctive and consistent. Branding improves the capacity to build a relationship between the SIMPO brand and customers. All these successful results are obtained through the combination of int. \& ext. branding. This illustrates that a combination of int. \& ext. branding can increase more adaptability/uniqueness/recognition. The connection of int. \& ext. branding ensures that people feel more confident to a company's brand. The connection of int. \& ext. branding keeps a certain brand more credible and attractive. Especially, internal branding requires the platform from external branding, and external branding requires executors or operators from internal branding. Success in SIMPO's case lies in the cooperation of int. \& ext. branding; these two factors cannot work separately. They should work closely. Therefore, in general, branding can add value to companies. Only the connection of int. \& ext. branding can add value to companies.

\section{The close connection between the internal \& external branding}

The combination of int. \& ext. branding gives SIMPO splendid results. Branding has delivered great service with satisfaction for customers and the company as well. At the same time, SIMPO also keeps a fast developing rate in the furniture industry. The SIMPO group brings more arability, uniqueness, recognition in this way. There are many examples that the SIMPO group ensure int. \& ext. branding work closely, as well as customer service staff may find that customers are easily getting too tired in the huge shopping centre when they walk around, especially the children always get tired. The front line employees feedback this information to design departments, and they cooperate with the design department to design more entertainment facilities and colourful display rooms as well as children's playrooms, restaurants, etc. (source from respondents). A single department cannot manage with brands by 
itself. Departments should always work together because they possess different knowledge, in other words, there is different information in connection with different functions. These departments in SIMPO always support, share information, knowledge, data, experience (etc.) with each other. They know brand does not belong to a single person, but it belongs to all of the staff, so they cooperate in teams to create a better brand. Another example, in 2011, SIMPO's product department planned to design a plush dog in both big and small series for the Asia Pacific market. Some staff in the customer service department disagreed regarding the size. They had (practical) working experience in Asian markets, and they realised that normal Chinese and Japanese families have a too limited room space to store very large plush dogs, and if it is too small, children are likely to put a small plush dog in their mouths. Finally, the different departments worked together to design a very successful product, which was then very well received in the Asian Pacific market. Every staff member has shown efficiency and effectiveness when it comes to responsibility for answering colleague's questions, customer's questions (data source from respondents). Corporate branding brings great value to this company. According to domestic daily business newspaper „Privredni pregled“ (www.pregled.rs, 2013) and from its primary international source weekly business magazine "Business Week" (www.businessweek.com, 2013), SIMPO is highly ranked regarding brand value. This means that SIMPO is among the leading brands in Eastern Europe furniture industry. Branding requires staff to operate, accomplish its aim. Internal factor can execute the external functions because staffs work directly in the Frontline. In the same way, external branding supplies a platform for the internal branding. Both int. \& ext. branding should work closely to increase customer's awareness and loyalty. Both int. \& ext. branding uses a different path to manage a brand, but they should combine by cooperating closely. Aaker and Jacobson (2001) said that branding could bring adaptability/uniqueness/recognition to companies, requiring the two factors work closely together. As earlier illustrated, external branding cannot work alone without internal branding in order to bring significantly more adaptability/uniqueness/recognition for a brand. Meanwhile, internal branding cannot work alone without external branding to bring more adaptability/uniqueness/recognition as well. Therefore, branding requires that int. \& ext. branding work closely together to when adding value. One of these two singled out is not enough to service branding in order to add value to companies. In that way, successful branding requires int. \& ext. branding to connect closely and work cooperatively. Real value derives from the combination of int. \& ext. branding. Branding really brings values for SIMPO, by way of the combination of int. \& ext. branding; branding can bring more adaptability/uniqueness/recognition as well as value to companies.

\section{SIMPO's further steps could lead to business entity transformation/change from an incubator to cluster}

The creation of clusters is not a government function, neither is it a tailor-made solution, and in fact, clustering involves many roles with each participant having certain duties, but the whole process needs coordination (Vanka and Heijman, 2013a). Additionally, Vanka and Heijman (2013a) suggest that the monitoring and supervision of the whole process, the identification of the needs and a permanent exchange between the participants are all organised as a cluster. Vanka and Heijman (2013a) also claim that one cluster can help to create another; where starting one process means that many others may follow. An SIMPO Line from Vranje in front of the wood - processing sector has singled out with five domestic companies that have represented out mapped region, and together with over twenty companies from other countries within the Adriatic Cluster Club Project have applied for project with inter-company B2B 
meetings which are planned during the phase of the realisation, and are in negotiations related to the realisation of the first concrete activities with the new partners. Complementarities between firms can help join the bidding and scale benefits on contract tenders; or joint marketing of products and services: when the producers have formed groups within one sector, it is already possible to organise joint marketing efforts toward consumers at the national level, as well as toward the domestic and foreign investors, in order to attract additional investments (Vanka et al., 2012). Vanka et al. (2012) also mentioned that a cluster constantly invests in marketing of location and industry, thus attracting buyers and making a landmark for the region. Later on, Vanka and Heijman (2013b) points out that cluster can also influence the local region as can a big corporation. The supported claim figures that a region's most famous product and companies are treated as regional landmarks (Vanka and Heijman, 2013b). The Adriatic economic cluster club is a project co-financed by the EU under the IPA Adriatic cross-border cooperation program. The aim of the project was to support the acceleration of the creation and strengthening of the cluster system in the nautical sector, the shipbuilding sector and related sub-sectors, with particular emphasis on the support of SMEs. For micro and small companies, according to Vanka and Heijman (2013b), clusters represent a chance to compete on the market and to attach the label of a recognisable brand; but for large companies, clusters are a way of controlling the local competition and the market, as well as of achieving export. Competition and the functioning of free markets guarantee the success of the sector and as a result, regional development (Vanka and Heijman, 2013a). The project also improved innovation of production systems, all through cooperation, development of business opportunities and market research. Within the project, a cross-border partnership has been established, consisting of sixteen partners from six different countries (Italy, Serbia, Croatia, Bosnia and Herzegovina, Greece and Albania), whose task consists in analysing existing clusters through mapping and identification of the manufacturing sector that is related with the nautical production chain, with special emphasis on following industries: wood industry, mechanical industry, chemical industry, metal industry and textile industry. In addition to that, the partnership promotes the exchange of best practice examples and experiences and entrepreneurial cooperation, as well as finding new business partners. Vanka and Heijman (2013b) suggest that a cluster can launch marketing campaigns and find new customers in international markets. Smaller companies can group functions such as marketing and logistics and outsource them to cluster (Vanka and Heijman, 2013b). The project that is primarily intended for SMEs also envisages business meetings which are held between the selected companies and research centres from different countries. Aforementioned complies with Vanka and Heijman (2013b) previous stands that from a marketing point of view, membership allows companies to present their products and services in a variety of places and occasions, in cooperation with service and government agencies. When a region has a successful cluster, this in a way brands the region and gives it additional value (Vanka and Heijman, 2013b). The benefits for the companies within clusters are the multiple linkages and synergistic/synergetic effects that help them to downsize costs, share knowledge, boost innovation and increase sales and exports; concluding that companies within clusters benefit from the cluster's reputation as a whole, as well as the actions such as fair trades, trade magazines and marketing delegations (Vanka et al., 2012). The project duration lasted until the end of August 2013; showing the project's success with such splendid results. In the end, complying with Vanka and Heijman (2013a) opinion, a win-win situation is created, even if the competition is raised to a higher level. 


\section{CONCLUSION}

This paper aimed to research if branding can be regarded as a means to add value to companies and the relationships between int. \& ext. branding when adding value to companies. The study discussed the close connection between branding and value; and about cooperative connections between int. \& ext. branding. External branding can supply the necessary platform and conditions for internal branding. Internal branding as an executor and an operator can help and support external branding (in order) to positively influence an enterprise value. Single int. $\&$ ext. branding ways is not enough to add value for companies; they should combine by working cooperatively and connecting closely. This is the way int. \& ext. branding connects to each other. The further growing of purchasing power of the population together with increasingly competitive credit terms offered by commercial banks will allow increasing the demand for durable goods such as furniture. Today, SIMPO is the largest furniture producer and among the largest companies in terms of turnover in Serbia. As far as its market position, SIMPO is positioned as number one domestic furniture producer with a strong and a recognisable brand name and a long tradition in the industry. The company has a distribution network, developed throughout Serbia and abroad, such as Russia, Germany, BosniaHerzegovina $(\mathrm{BiH})$ and Macedonia. Numerous high street outlets located in all major cities in Serbia give SIMPO the unparalleled competitive reach/range. The SIMPO case illustrates that the combination of int. \& ext. branding is a significant part in the path to bring more adaptability/uniqueness/recognition to a company. Branding is really a means to add more value for companies. Successful branding may provide a company with a differential advantage and values. It keeps the corporate brand interesting and fresh by renewing old products, it creates a desire in saturated markets, and besides that, it is a source of competitive advantage. Int. \& ext. branding may become significant solutions to consolidate the company's market position and be instructive for a company's potential reaction to different market conditions. Vanka (2011) points out that it is the game of right positioning at the right time for a corporate brand to make more as well as loyal customers. Firms must first ensure that the customer need is addressed by positioning offers or other marketing-driven content in the context of the interaction (Vanka 2011). The discussion in this article shows how companies manage their brands and what factors are in the game when managing a brand. The int. \& ext. branding tools are the significant tools when improving an enterprise value. The work here has not focused much on the customer's behaviour and organisational performance, as well as the connection with the relationship between a company's human resource administration and public relations (PR). If there is the possibility to research further this point, it will discuss them connected with consumer behaviour and organisational performance as well as public relationships. 


\section{REFERENCES}

[1] Aaker, D. (1996). Building Strong Brands, Free Press, New York, NY.

[2] Aaker, D. A., and Joachimsthaler, E. (2000). Brand Leadership: The Next Level of the Brand Revolution, The Free Press, New York, NY., Pp. 1 - 6. ISBN 0-684-83924-5.

[3] Aaker, D. A., and Jacobson, R. (2001). "The value relevance of brand attitude in hightechnology markets", Journal of marketing research, Pp. 485 - 493.

[4] Achrol, R. S. (1991). "Evolution of the Marketing Organisation: New Forms for Turbulent Environments", Journal of Marketing, Vol. 55, Pp. 77 - 93.

[5] Ashtiani, P. G., \& Bahmanzadeh, F. (2017). Evaluate the effectiveness of advertising on customers' willingness to buy (Case study: Goldiran products customers). International Review, (3-4), 118-129.

[6] Balmer, J. M. T., and Wilkinson, A. (1991). "Building societies: change, strategy and corporate identity", Journal of General Management, Vol. 17 No. 2, Pp. 20 - 33.

[7] Balmer, J. M. T. (1995). "Corporate branding and connoisseurship", Journal of General Management, Vol. 21 No. 1, Pp 24 - 46, Left Book Club, London.

[8] Brown, S., Kozinets, R. V., Sherry, J. F. (2003). "Teaching old brands new tricks: retro branding and the revival of brand meaning", Journal of Marketing, Vol. 67 No.3, Pp. 19 33, University of Wales Press, London. Available at http://lwww3.nd.edu/ jsherry/pdf/2003/Teaching\%20Old\%20Brands\%20New\%20Tricks. pdf (accessed February 2018).

[9] Coupland, J. C., Iacobucci, D., Arnould, E. (2005). "Invisible brands: an ethnography of households and the brands in their kitchen pantries", Journal of Consumer Research, Vol. 32 No.1, New York.

[10] Davis, S. (1995). "A vision for the year 2000: brand asset management", Journal of Consumer Marketing, Vol. 12 No.4, Pp. 65 - 82, Pergamon Books, Chicago.

[11] De Chernatony, L., and McDonald, M. (1992). Creating Powerful Brands, Butterworth Heinemann, Oxford University Press Oxford.

[12] De Chernatony, L., Harris, F., Riley, D. (2000). "Added value: its nature, roles and sustainability", European Journal of Marketing, Vol. 34 No.1/2, Pp 39 - 56, Robson Books London.

[13] Drees, S. (2006). "Creating Lasting, Profitable Customer Loyalty in Highly Competitive Markets: The Six P's of Loyalty“", The Allegiant Group, Inc., Cincinnati, OH, US, Working paper, No. 1, August 2006, Available at www.brandchannel.com (accessed May 2018).

[14] Jones, G. and Morgan, N. J. (1994). Adding Value, Routledge, London.

[15] Kapferer, J. N. (1992). Strategic Brand Management, Pathfinder Books, London.

[16] Keller, K. L. (1993). "Conceptualizing, measuring and managing customer-based brand equity”, Journal of Marketing, Vol. 57, January, Pp. 1 - 22.

[17] Keller, K. L. (1999). "Brand mantras: rationale, criteria and examples", Journal of Marketing Management, Vol. 15, Scarecrow Press, Berlin.

[18] Keller, K. L. (2000). "Building and Managing Corporate Brand Equity”, in Majken Schultz, Mary Jo Hatch (ed.) (2000), The Expressive Organisation, Oxford University Press.

[19] Knox, S. D., and Walker, D. R. (1995). "Empirical developments in the measurement of involvement, brand loyalty and their structural relationships in grocery markets", Cranfield School of Management Working Paper Series S.W.P. 12/95., The New Press, New York.

[20] Knox, S. D. and Maklan, S. (1998). Competing on Value: Bridging the Gap Between Brand and Customer Value, Financial Times (F.T.) Pitman Publishing, London. 
[21] Knox, S. D., Maklan, S., and Thompson, K. E. (2000). "Building the unique organisation value proposition", in Schultz, M., Hatch, M. J., Larsen, M. H. (ed.) (2000), The Expressive Organisation \pm Linking Identity, Reputation, and the Corporate Brand, Oxford University Press, Oxford, Pp. 138 - 156.

[22] Kotler, P. (1997). Marketing Management: Analysis, planning, implementation, and control, $9^{\text {th }}$ ed., Prentice Hall, Upper Saddle River, NJ.

[23] Kotler, P. (1998). Marketing Management, $8^{\text {th }}$ ed., Prentice-Hall, New York, NY.

[24] Krake, F. B. (2005). "Successful brand management in SMEs: a new theory and practical hints". Journal of Product \& Brand Management, 14(4), 228 - 238.

[25] Lotfifard, S., \& Borojerdi, P. N. (2018). Study and Evaluate the Effect of Marketing Mix on Export Performance (Case Study: Nestle Corporation in Qazvin Province). International Review, (1-2), 73-82.

[26] McCracken, G. (1993). "The value of the brand: an anthropological perspective", Pp. 125 - 39, Lawrence Erlbaum Associates, Hillsdale, NJ. Available at www.brandchannel.com (accessed May 2018).

[27] Pitta, D. A., and Katsanis, L. P. (1995). "Understanding brand equity for successful brand extension". Journal of consumer marketing, 12(4), Pp. 51 - 64.

[28] Randazzo, S. (1993). Mythmaking on Madison Avenue, Probus, Chicago.

[29] Robbins, S. P. (1990). Organisation Theory: Structure, Design and Theory, $3^{\text {rd }}$ ed., Prentice Hall, Englewood Cliffs.

[30] Ryder, R. D. (2003). Brands, trademarks, and advertising, LexisNexis Butterworths.

[31] Satvati, R. S., Rabie, M., \& Rasoli, K. (2016). Studying the relationship between brand equity and consumer behavior. International Review, (1-2), 153-163.

[32] Sherry, J. (1998). "The soul of the company store: Niketown Chicago and the emplaced brandscape", in Sherry, J. The Concept of Place in Contemporary Markets, NTC Business Books, Lincolnwood.

[33] Speak, K. D. (1998). "Brand Stewardship", Design Management Journal (Former Series), Winter, 9 (1), Pp. 32 - 37.

[34] Stosic Mihajlovic, Lj. (2013). "Design, Innovation and Personalisation - The Main Asset Company "SIMPO", Vranje", (JPMNT) Journal of Process Management - New Technologies, International, Vol. 1, No.3, Pp. 58 - 61. Available at https://scindeksclanci.ceon.rs/data/pdf/2334-735X/2013/2334-735X1303058S.pdf (accessed May 2018)

[35] Upshaw, L. B. (1995). Building Brand Identity: A strategy for success in a hostile marketplace, John Wiley and Sons, New York, NY.

[36] Vanka, G. M. (2011). "Corporate branding effects on consumer purchase preferences in Serbian telecom market". APSTRACT: Applied Studies in Agribusiness and Commerce, Vol. 5, Pp. $91-104$.

[37] Vanka, G. M., Heijman, W. J. M., Vasiljevic, Z. (2012). "Present state analysis of cluster initiatives in Serbian transition economy". Agricultural Economics - Czech, Vol. 58 No. 12 , Pp. $566-579$.

[38] Vanka, G. M., Heijman, W. J. M. (2013a). "The Kosovar wine cluster: A booster for regional development?". Agricultural Economics - Czech, Vol. 59 No. 4, Pp. 167 - 182.

[39] Vanka, G. M., Heijman, W. J. M. (2013b). "An assessment of the economic value of clusters and their influence on companies in the Serbian transition economy". Agricultural Economics - Czech, Vol. 59 No. 9, Pp. $403-419$.

[40] Van Kralingen, R. (2002). Brand world, rethinking branding, Princeton University Press, Princeton. 
[41] Voerman, J. A. (2003). Export Performance of European SME's, Rijks universiteit press, Groningen.

[42] Vossoughi, S. (1999). "Brand is the thing", Design Management Journal, Webster, K Oxford University Press, New York.

[43] Wernick, A. (1991). Promotional culture: Advertising, ideology and symbolic expression

- Theory, culture \& society, Sage Publications, Inc., Thousand Oaks, CA, US.

[44] http://www.businessweek.com [Accessed 08/02/18]

[45] http://www.pks.rs [Accessed 08/03/18]

[46] http://www.pregled.rs [Accessed 04/04/18]

[47] http://www.simpo.rs [Accessed 01/12/17]

[48] http://www.simpogroup.com [Accessed 08/03/18]

\section{Article history:}

- Received 30 November 2018

- Accepted 12 May 2019 